\title{
What Are Journalists For?
}




\section{Jay Rosen What Are}

YALE UNIVERSITY PRESS/ NEW HAVEN AND LONDON 
Journalists For 
Published with assistance from the Tew Memorial Fund.

Copyright $\odot 1999$ by Yale University. All rightes reserved. This book may not be reproduced, in whole or in part, including illustrations, in any form (beyond that copying permitted by Sections 107 and 108 of the U.S. Copyright Law and except by reviewers for the public press), without written permission from the publishers.

Designed by Nancy Ovedovitz and set in Adobe Garamond type by Keystone Typesetring, Inc. Orwigsburg, Pennsylvaniz. Printed in the United States of America by Vail-Ballou Press, Binghamton, New York.

Library of Congress Cataloging-in-Publication Data

Rosen, Jay, 1956-

What are journalists for? / Jay Rosen.

p. $\quad \mathrm{cm}$.

Includes bibliographical references and index.

ISBN 0-300-07823-4 (cloch : alk. paper)

ISBN 0-300-08907-4 (pbk. : alk. paper)

I. Journalism-Social aspects. 2. Journalism-Social aspects-

United States. 3. Journalism-Objectivity. 4. Journalistic

ethics. I. Title.

PN 4749.R668 2000

302.23'0973-dC2I 99-2989I

A catalog record for this book is available from the British Library.

The paper in this book meets the guidelines for permanence and durability of the Committee on Production Guidelines for Book Longevity of the Council on Library Resources.

10 987765432 
To Hali 
This page intentionally left blank 